\title{
PARTICLE MORPHOLOGY, COMPOSITION AND ASSOCIATED ICE CHEMISTRY OF TEPHRA LAYERS IN THE BYRD ICE CORE: EVIDENCE FOR HYDROVOLCANIC ERUPTIONS
}

\author{
by \\ J.M. Palais \\ (Institute of Polar Studies and Department of Geology and Mineralogy, Ohio State University, \\ Columbus, Ohio 43210, U.S.A.)
}

\section{ABSTRACT}

In 1968 an ice core $2164 \mathrm{~m}$ long was recovered from Byrd station in West Antarctica. About 2000 tephra layers were observed in the core and have been differentiated into ash and dust bands according to the grain size and concentration of particles in the layers. Mount Takahe, a local volcano in Marie Byrd Land, Antarctica is the probable source.

Detailed examinations of the particle morphology, composition and ice chemistry associated with some of the tephra layers have led to the conclusion that the eruptions which produced the layers were probably hydrovolcanic. Melted glacier ice is considered the most likely source of the water involved in the eruptions.

Processes associated with hydrovolcanism such as particle aggregation (causing premature deposition of fine particles), rapid conversion of sulfur dioxide to sulfuric acid (in the presence of abundant moisture) and scavenging of acid droplets by the fine dust particles are inferred to have taken place. Such processes would greatly reduce the atmospheric residence time of the eruptive products and thus their atmospheric and climatic impact.

\section{INTRODUCTION}

Deep ice cores from the polar regions of Antarctica and Greenland contain extensive records of paleoclimate and paleoatmospheric composition in the form of soluble and insoluble impurities, stable isotope variations and gases trapped in air bubbles in the ice. The interpretation of these records from a global point of view requires knowledge of the local factors which could affect the record.

In 1968 an ice core $2164 \mathrm{~m}$ long was recovered from Byrd station in West Antarctica $\left(80^{\circ} 01^{\prime} \mathrm{S}, 119^{\circ} 31^{\prime} \mathrm{W}\right.$, altitude $1530 \mathrm{~m})$. In addition to studies of the ice-crystal size, fabric, density, air bubbles, stable isotopes, ice chemistry, microparticles and the basal ice (Gow and others 1968, Thompson and others 1975, Cragin and others 1977), preliminary examination of the core revealed the presence of about 2000 volcanic ash and dust layers (tephra) which were examined by Gow and Williamson (1971) and more recently by Kyle and Jezek (1978) and Kyle and others (1981, 1982).

The purpose of the present study is to seek supporting evidence that Mount Takahe in West Antarctica is the source of the tephra as proposed by Kyle and Jezek (1978) and to provide information regarding the probable nature of the eruptions and the likely atmospheric and climatic impact they had. In addition, the results of this study may establish criteria which should be useful in the interpretation of tephra layers in other deep ice cores. The results include studies of the particle morphology, composition and ice chemistry of several of the tephra layers in the Byrd core.

\section{PREVIOUS WORK}

Gow and Williamson (1971) made the first detailed study of the 25 dirt and other (c. 2000) cloudy layers in the Byrd core. These layers were differentiated into volcanic ash and dust bands according to the mean grain size and concentration of particles in the layers, as summarized below.

\begin{tabular}{lcc}
\multicolumn{1}{c}{ Parameter } & Ash & Dust \\
Concentration $\left(\mathrm{g} \mathrm{cm}^{-3}\right)$ & $10^{-3}$ & $10^{-5}$ \\
Mean size $(\mu \mathrm{m})$ & 50 & $1-2$ \\
Composition & lithic & vitric \\
& vitric & crystal \\
& crystal & \\
& & \\
$\begin{array}{l}\text { Approximate } \\
\text { depth }(\mathrm{m})\end{array}$ & 788, & 911, \\
& $1300-1800$ & $1200-2000$
\end{tabular}

(especially $1300-1400$ )

The most likely source of these ash and dust (tephra) layers was believed to be the volcanoes of Marie Byrd Land although a more distant source for the dust layers was not ruled out.

Kyle and Jezek (1978) examined glass shards and lithic particles from three of the ash bands by electron microprobe analysis and classified the glass as peralkaline trachyte. They suggested that Mount Takahe, a young $(<0.25$ Ma BP (LeMasurier 1972)) volcano located about $450 \mathrm{~km}$ from Byrd station is the probable source. Kyle and others (1981) later confirmed these conclusions after studying several additional ash layers from the Byrd ice core and suggested that the eruptions were probably phreatomagmatic or surtseyan in nature.

Ragone and Finelli (1972), Cragin and others (1977) Kyle and others (1982) and Palais and Legrand (1985) have studied the major soluble impurities in the Byrd ice core. These studies have shown that most ionic species had elevated concentrations during the last glacial period. Ragone and Finelli (1972) speculated that the volcanism recorded in the core might be responsible for these elevated concentrations whereas Cragin and others (1977) appealed to important influxes of eolian dust into Antarctica from other parts of the globe.

Palais and Legrand (1985) were able to show that, on the average, ionic impurities in the Byrd core are in charge balance and that marine $\mathrm{NaCl}$ and $\mathrm{Na}_{2} \mathrm{SO}_{4}$ are a major component of these impurities. The gas-derived acids $\mathrm{HNO}_{3}$, $\mathrm{HCl}$ and $\mathrm{H}_{2} \mathrm{SO}_{4}$ were also found to be important in the ionic balance of the Byrd core ice. Palais and Legrand suggested that turbulence in the atmosphere, resulting from stronger meridional circulation increased the atmospheric loading of marine impurities during the last glacial period while increased biogenic productivity or local volcanism might have been responsible for the increase in gas-derived excess sulfate. These studies provide a useful foundation from which to examine whether the volcanism recorded in the Byrd core affected atmospheric chemistry and thus the composition of the precipitation deposited at Byrd station.

\section{SAMPLING AND ANALYTICAL METHODS}

Samples from 23 sections of the Byrd core were examined in this study. Because none of the 25 ash layers, originally described by Gow and Williamson (1971), have remained intact in the core, this sampling was limited to 
ice with dust bands and clear ice. However, tephra samples which had been retained on filters from 15 of the 25 original ash layers were available for SEM, EDAX and electron microprobe analyses.

Samples were prepared using the "wet" cleaning procedure described by Langway and others (1974) for use with ice cores in which a drilling fluid had contaminated the core exterior. More than $50 \%$ of the original sample may have been removed in this process. Washed samples were placed in clean plastic cups and allowed to melt Melted samples were placed in Coulter ${ }^{\mathrm{TM}}$ accuvettes and refrozen until the time of analysis. Two accuvettes of about 20 to $25 \mathrm{ml}$ were obtained from each sample, one of which was used for ice chemistry and the other was used for grain-size analyses and filtering for examination of the dust.

\section{Tephra morphology and composition}

An ISI model S-111A scanning electron microscope equipped with a Kevex 7000 series Quantex ray ${ }^{\mathrm{TM}}$ ux analytical spectrometer was used to examine individual tephra particles. Working distances were typically 20 to $30 \mathrm{~mm}$ and an accelerating voltage of $15 \mathrm{kV}$ was used for imaging and EDAX analyses. The Quantex ray standardless EDS analysis uses ZAF corrections via MAGIC (Kevex Corporation 1980). Oxide concentrations from elemental peak intensities and theoretical standards are calculated and compared. Unknown elemental concentrations are then approximated and given as oxide weight percents normalized to $100 \%$.

Electron microprobe analyses of particles from five ash layers were made using a 3-channel Camebax automated microprobe. An accelerating voltage of $15 \mathrm{kV}$, speciment current of $0.012 \mu \mathrm{A}, 10-15 \mu \mathrm{m}$ beam size and a minimum of 5-second count times were used. Data were corrected using the Bence-Albee matrix correction procedure (Bence and Albee 1968). Several glass and feldspar standards were used to check accuracy and monitor $\mathrm{Na}_{2} \mathrm{O}$ and $\mathrm{K}_{2} \mathrm{O}$ concentrations. Typical precision for most elements was from 1 to $5 \%$ of the mean value.

\section{Ice chemistry}

Melted ice samples were measured for conductivity, acidity, sulfate, nitrate, total sodium and aluminum depending on the availability of liquid. Conductivity and acidity measurements were made using a method of standard addition developed by Legrand (1980) and discussed in detail by Legrand and others $(1982,1984)$. The precision of these measurements was estimated to be $\pm 0.03 \mu \mathrm{S} \mathrm{cm}$ at the $95 \%$ confidence interval for conductivity and $\pm 0.2 \mu \mathrm{eq} \mathrm{I}^{-1}$ at the $95 \%$ confidence interval for acidity (Legrand and others 1984).

During these measurements a phenomenon was observed which deserves to be mentioned. It was noted that samples, which contained abundant silicate dust, consistently had low acidity and of ten high conductivity. During the measurements of these samples, readings of the conductivity meter and hydrogen ion electrode potention were very unstable as if reactions were taking place. Several experiments were undertaken in which known amounts of volcanic glass were added to solutions of known acidity and it was confirmed that the presence of silicate dust did affect the acidity and conductivity of samples with low $(\mathrm{ppb})$ concentrations of ionic impurities. Acidities were found to decreased by 15 to $70 \%$ of the initial acidity for additions of dust between 30 to $430 \mathrm{ppm}$. The greater the concentration of dust the greater was the decrease of acidity. The reaction that causes this effect may be silicate hydrolysis which tends to neutralize the acidity initially present in the ice and could make the meltwater alkaline. The liquid conductivity of such samples may increase because of the liberation of ions from the silicate in exchange for $\mathrm{H}^{+}$ions.

Sulfate and nitrate were measured using a Dionex model 10 ion chromatograph. The working conditions and precision of these measurements are discussed in detail by Legrand and others (1984). In general the detection limit is about $1 \mathrm{ppb}\left(0.02 \mu \mathrm{eq} 1^{-1}\right)$ for all ions and the precision is about $\pm 0.2 \mu \mathrm{eq} 1^{-1}$ for sulfate and $\pm 0.1 \mu \mathrm{eq} 1^{-1}$ for nitrate. The concentrations of unknown samples were determined by comparing peak heights with those of calibration solutions.

Total sodium and aluminum were measured using a Perkin Elmer model 303 flameless atomic absorption unit equipped with a graphite furnace (model HGA-70). Calibration solutions ( 0 to $200 \mathrm{ppb}$ ) were prepared using Orion $^{\mathrm{TM}}$ standards. These solutions were run systematically before and after each series of measurements to allow correction for instrument drift and to determine concentrations of unknown samples. Typical values of analytical precision are about $5 \%$ for both sodium and aluminum (de Angelis and others in press).

\section{RESULTS}

Tephra morphology and composition

The interaction of magma or magmatic heat in the near-surface environment with large quantities of water (sea-water, groundwater, lake-water or glacial ice) produces highly explosive volcanic eruptions and other phenomena known collectively as hydrovolcanism (Sheridan and Wohletz 1983). In hydrovolcanic eruptions the mixing of magma and water (phreatomagmatic eruptions vs phreatic, in which no fresh magma is discharged) and the high degree of fragmentation which accompanies such an eruption, produces an initial population of very fine-grained (millimeter to sub-millimeter) pyroclastic material composed of abundant lithic particles, crystals and glass shards (Walker 1971, Rose and Hoffman 1982, Rose and others 1983).

According to Heiken (1974), tephra produced in hydrovolcanic eruptions are characterized by equant, blocky grains with curviplanar surfaces and few vesicles. If vesicles do occur they range from spherical to elongate depending on the viscosity of the magma. Flat, elongate, pyramidal and drop-like particles are also common. Fine micron-size dust often adheres or is partially fused to the other particles. In extreme cases, aggregates are formed when fine ash particles of this kind become agglutinated or when fine particles coat larger ones (Wohletz 1983, K H Wohletz and D H Krinsley personal communication).

In addition to their shape, hydrovolcanic particles can be recognized by a number of surface microfeatures including conchoidal fractures, v-shaped depressions, upturned plates, grooves, cracks, adhering particles and chemical alteration (sublimates, clays and zeolites (palagonite)) which form during eruption, transport and deposition of the ash (Heiken 1974, Rose and others 1982, Wohletz 1983, K H Wohletz and D H Krinsley personal communication). The particles from the ash and dust layers examined in this study have many of the features characteristic of hydrovolcanic tephra. These are described below.

\section{$\underline{\text { Ash }}$}

The most prominent feature of the tephra particles in the ash layers is their morphological and compositional homogeneity. Except for an occasional lithic or crystal most of the particles in the ash layers are blocky or platy shards of low vesicularity (Figs. 1(a) and (b)). Where vesicular particles do occur they are usually only fragments with thick bubble walls and ovoid, elliptical or elongate pipe vesicles (Figs. 1(c) and (d)). In some samples fine dust adheres to the ash particles (Figs. 1(a), (b), and (c) and some particles are aggregates of smaller fragments (Fig. 1(a)).

Electron microprobe analyses of particles from five ash layers (including four not previously analyzed) are listed in Table I. Comparison of these analyses with data from Kyle and others (1981) provides additional support for the conclusion that all ash layers in the core have the same source. Mount Takahe, one of the youngest volcanoes $(<0.25$ $\mathrm{Ma})$ in the Marie Byrd Land province of West Antarctica is still the preferred source (Kyle and Jezek 1978). Figure 2 is a plot of the mean weight percent of $\mathrm{SiO}_{2}$ in particles from the tephra layers analyzed in this study and by Kyle and others (1981). The compositional similarity of all the ash layers examined is particularly interesting for it suggests that the volcano maintained the same composition during the time that it was active $(>20 \mathrm{ka})$.

EDAX analyses of 12 ash layers were made to provide 


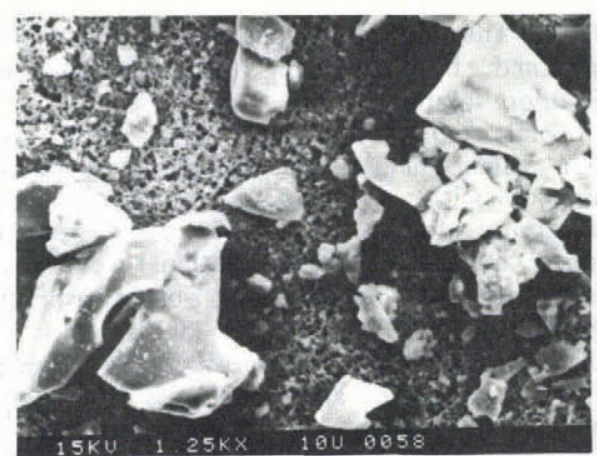

a

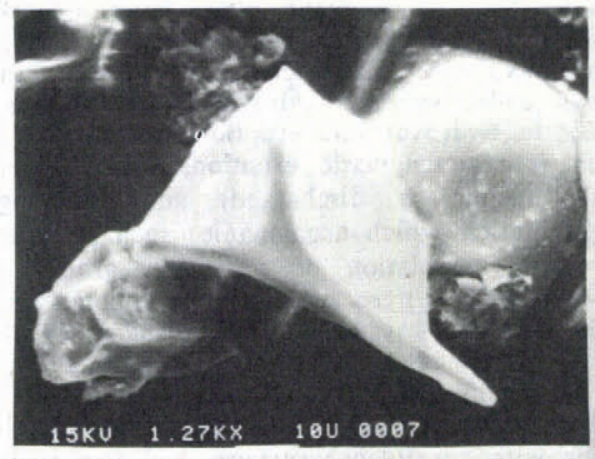

(6)

Fig. 1. SEM photographs of particles from ash layers: $1558 \mathrm{~m}$, blocky shards and crystals (?), (c) $1458 \mathrm{~m}$, bubble wall shard, (d) $1616 \mathrm{~m}$, pipe vesicles, elongate shard.

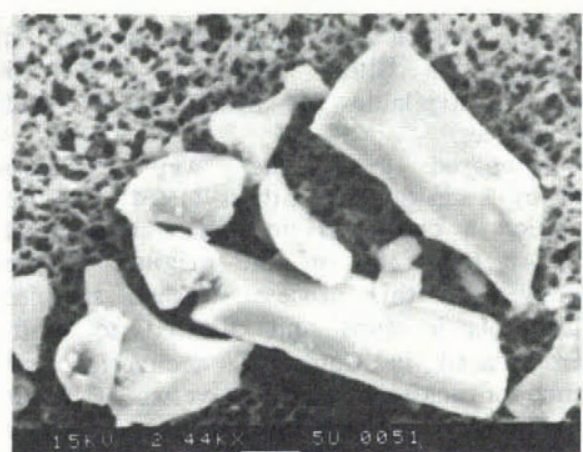

b

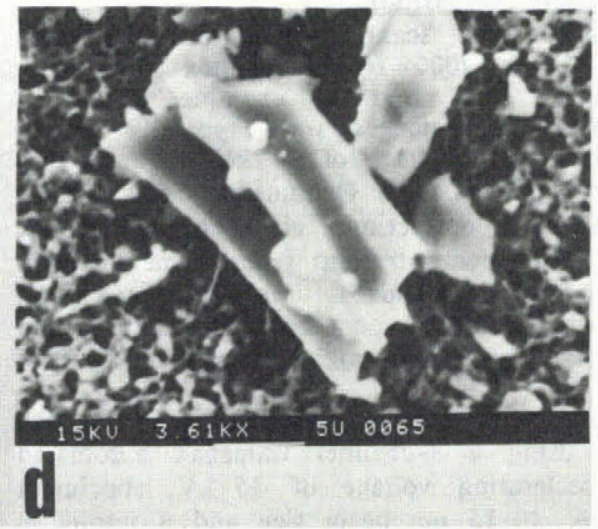
(a) $1581 \mathrm{~m}$, blocky and platy shards, (b)
ubble wall shard, (d) $1616 \mathrm{~m}$, pipe vesicles,
The particles which are most characteristic of the dust layers are the aggregates, such as those pictured in Figures 3(a) and (b). In Figure 3(a), the individual particles are probably a mixture of vitric and crystal fragments whereas in Figure 3(b) the particles seem to be entirely crystal fragments.

These aggregates are very similar to particles which have been described by Sorem (1982), Rose and Hoffman (1982) and Rose and others (1983) from hydrovolcanic eruptions. Several mechanisms have been proposed to explain the formation of these aggregates (Sorem 1982, Rose and Hoffman 1982). The presence of abundant moisture (including $\mathrm{H}_{2} \mathrm{SO}_{4}$ droplets) and fine dust (which promotes electrostatic attractions) such as would be present in a hydrovolcanic eruption are two features which seem to be characteristic of all eruptions in which aggregates have been found.

Other types of particles which are found in the dust layers include mineral fragments (Fig. 3(b)), spheres (Fig. 3(c)) and altered lithic fragments (Fig. 3(d)). Many of these particles have surface features like those described by Wohletz (1983) such as grooves, pits, cracks, plates, adhering particles and chemical alteration. These features are especially obvious in Figures $3(\mathrm{c})$ and (d).

Detailed studies of the individual particles in the dust layers show that they have similar chemical compositions (when calculated on a S- and $\mathrm{Cl}$-free basis) and probably have the same source as the ash layers. In addition to vitric dust particles with compositions nearly identical to the glass shards from the ash layers there are abundant crystal (e.g. feldspar, pyroxene, oxides) and lithic fragments.

In Figure 2, the mean $\mathrm{SiO}_{2}$ (weight \%) values of 10 of the dust layers which were examined are plotted. Although the mean $\mathrm{SiO}_{2}$ of the dust layers in the interval between 1300 and $1350 \mathrm{~m}$ appears to be lower than the mean of the ash layers this is probably because of the abundant lithic and crystal fragments (which tend to have lower $\mathrm{SiO}_{2}$ ) which have been averaged in with the analyses. On this figure is also plotted the mean $\mathrm{SiO}_{2}$ of all the ash and dust samples from this study and the work of Kyle and others 
TABLE I. MAJOR ELEMENT ANALYSES (WEIGHT \%) OF VOLCANIC GLASS FROM TEPHRA LAYERS IN THE BYRD ICE CORE AND COMPARATIVE ANALYSIS OF VOLCANIC ROCKS FROM MOUNT TAKAHE

\begin{tabular}{|c|c|c|c|c|c|c|c|}
\hline Sample & 1 & 2 & 3 & 4 & 5 & 6 & 7 \\
\hline Tube number & 915 & 959 & 1013 & 1047 & 1061 & & \\
\hline Depth of sample (m) & 1436 & 1500 & 1581 & 1631 & 1653 & & \\
\hline $\begin{array}{l}\text { Number of measurements } \\
\text { on sample }\end{array}$ & 21 & 8 & 10 & 12 & 8 & & \\
\hline $\mathrm{SiO}_{2}$ & $63.61(0.59)$ & $63.53(0.67)$ & $62.17(0.35)$ & $63.13(0.35)$ & $64.04(0.69)$ & $61.90(0.40)$ & 61.22 \\
\hline $\mathrm{TiO}_{2}$ & $0.37(0.07)$ & $0.43(0.05)$ & $0.41(0.02)$ & $0.44(0.04)$ & $0.42(0.12)$ & $0.54(0.06)$ & 0.61 \\
\hline $\mathrm{Al}_{2} \mathrm{O}_{3}$ & $15.46(0.51)$ & $14.93(0.05)$ & $14.24(0.19)$ & $15.33(0.16)$ & $15.59(0.77)$ & $15.01(0.25)$ & 15.16 \\
\hline $\mathrm{FeO}^{(\mathrm{a})}$ & $6.81(0.91)$ & $7.07(0.51)$ & $8.70(0.29)$ & $6.99(0.35)$ & $5.37(1.35)$ & $7.90(0.25)$ & 7.07 \\
\hline $\mathrm{MnO}$ & $0.20(0.03)$ & $0.34(0.03)$ & $0.36(0.02)$ & $0.25(0.01)$ & $0.21(0.05)$ & not analyzed & 0.29 \\
\hline $\mathrm{MgO}$ & $0.02(0.01)$ & $0.04(0.01)$ & $0.06(0.01)$ & $0.11(0.01)$ & $0.08(0.03)$ & $0.12(0.05)$ & 0.12 \\
\hline $\mathrm{CaO}$ & $0.91(0.14)$ & $1.01(0.07)$ & $1.02(0.03)$ & $1.03(0.04)$ & $0.80(0.14)$ & $1.28(0.13)$ & 1.30 \\
\hline $\mathrm{Na}_{2} \mathrm{O}$ & $9.65(0.22)$ & $7.04(0.43)$ & $7.01(0.60)$ & $7.47(0.23)$ & $6.35(0.70)$ & $7.83(0.23)$ & 7.97 \\
\hline $\mathrm{K}_{2} \mathrm{O}$ & $4.84(0.13)$ & $4.74(0.28)$ & $4.60(0.05)$ & $4.90(0.04)$ & $5.25(0.28)$ & $4.51(0.06)$ & 4.80 \\
\hline $\mathrm{P}_{2} \mathrm{O}_{5}$ & $\begin{array}{l}\text { not } \\
\text { analyzed }\end{array}$ & $\begin{array}{c}\text { not } \\
\text { analyzed }\end{array}$ & $\begin{array}{c}\text { not } \\
\text { analyzed }\end{array}$ & $\begin{array}{c}\text { not } \\
\text { analyzed }\end{array}$ & $\begin{array}{c}\text { not } \\
\text { analyzed }\end{array}$ & $0.09(0.02)$ & 0.11 \\
\hline Total & 99.86 & 99.12 & 98.57 & 99.65 & 98.11 & 99.18 & $98.65^{(d)}$ \\
\hline \multicolumn{8}{|l|}{ CIPW norms (wt \%) } \\
\hline Q & 0.12 & 1.98 & 0.54 & - & 3.42 & 0.61 & - \\
\hline Or & 28.36 & 27.80 & 27.24 & 28.91 & 31.14 & 26.62 & 28.36 \\
\hline $\mathrm{Ab}$ & 52.92 & 50.30 & 47.68 & 51.35 & 50.83 & 50.46 & 50.15 \\
\hline $\mathrm{Ne}$ & - & - & - & - & - & 0.89 & 0.60 \\
\hline Ac & 5.08 & 5.08 & 6.47 & 5.08 & 2.31 & 6.16 & 5.67 \\
\hline Ns & 1.34 & 0.85 & 0.98 & 1.34 & 00 & 1.66 & 2.27 \\
\hline Di & 2.11 & 2.38 & 2.38 & 2.34 & 1.85 & 5.13 & 5.08 \\
\hline Hy & 9.87 & 10.66 & 13.80 & 10.50 & 7.59 & 3.24 & - \\
\hline $\mathrm{O} 1$ & - & - & - & - & - & 3.36 & 5.29 \\
\hline Mt & - & - & - & - & 0.70 & 0.10 & - \\
\hline I1 & 0.76 & 0.76 & 0.76 & 0.91 & 0.76 & 0.92 & 1.16 \\
\hline Ap & - & - & - & - & - & 0.20 & 0.26 \\
\hline Total & 100.56 & 99.81 & 99.85 & 100.43 & 98.60 & 99.35 & 98.84 \\
\hline $\mathrm{DI}^{(\mathrm{c})}$ & 81.4 & 80.1 & 75.5 & 80.3 & 75.4 & 78.6 & 79.1 \\
\hline
\end{tabular}

Key 1-5: ash layers from Byrd station, 6: mean of analyses of six ash layers $(788 \mathrm{~m}, 1457 \mathrm{~m}$, $1487 \mathrm{~m}, 1500 \mathrm{~m}, 1594 \mathrm{~m}, 1711 \mathrm{~m}$, number of samples: 101) from Byrd station analyzed by Kyle and others 91981), 7: peralkaline trachyte (66A) from Mount Takahe (W LeMasurier personal communication to $\mathrm{P}$ Kyle and others 1981), number in parentheses ( $\bar{\sigma})$ represents one standard deviation of the mean.
(a) $[\mathrm{Fe})$, total $\mathrm{Fe}$ as $\mathrm{FeO}$.
(b) for the norm calculation $\mathrm{Fe}_{2} \mathrm{O}_{3}$ standardized at $0.25 \times[\mathrm{FeO}$.
(c) differentiation index 9Thornton and Tuttle 1960).
(d) includes $\mathrm{H}_{2} \mathrm{O}^{+}=0.37$.

(1981). The $\mathrm{SiO}_{2}$ value from Mount Takahe is also plotted. The similarity of these mean values is a good indication that all the tephra layers (ash and dust) in the Byrd core were erupted from Mount Takahe.

The $\mathrm{S}$ and $\mathrm{Cl}$ surface alteration which was found on some ash particles was also present on many of the dust particles and is believed to be related to processes that occurred during the eruptions which deposited S- and $\mathrm{C} 1$-bearing compounds of the particle surfaces. The $\mathrm{S} / \mathrm{C} 1$ ratios calculated for the particles in the dust layers range from 0.57 to 1.89 and are plotted on the right side of Figure 2. These ratios are somewhat lower and have a much narrower range than the values calculated for the ash layers. As discussed by Gandrud and Lazrus (1981), abundant water in a volcanic plume would tend to reduce the solubility of
$\mathrm{SO}_{2}$, increase the solubility of $\mathrm{HCl}$, and cause a selective enrichment of $\mathrm{Cl}$ (lower $\mathrm{S} / \mathrm{Cl}$ ratio) on acid-coated particles. The differences between the $\mathrm{S} / \mathrm{Cl}$ ratios on the ash and dust particles may be due in some cases to changes in the composition or the contribution of the magmatic gas component in the eruptions. However if a large amount of water were involved in the eruption of some of the layers this could have the same effect on the $\mathrm{S} / \mathrm{Cl}$ ratios as compositional changes in the magma. Based on the finer grain size and the morphology of particles in the dust layers as well as the low $\mathrm{S} / \mathrm{Cl}$ ratios on the dust particles it is believed that water may have been more abundant and the eruptions may have been more explosive in the dust as compared to some of the ash eruptions. 

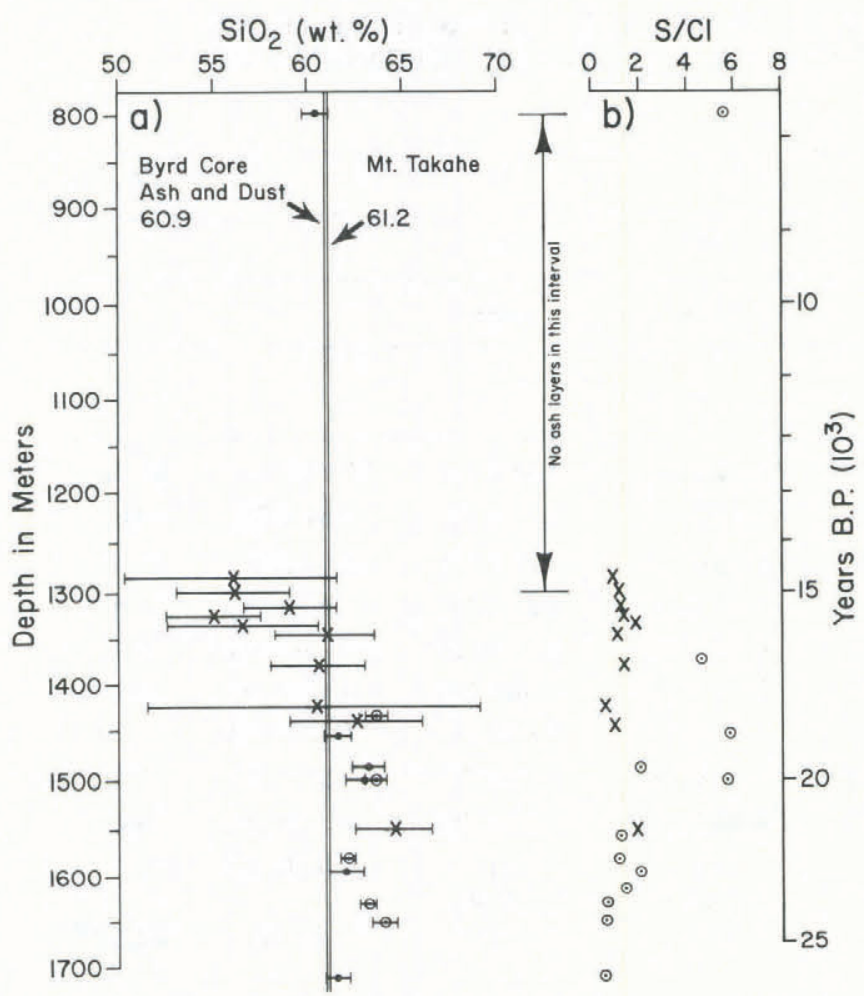

Ash - Kyle, and others (198I) Ash $\odot$ This work

Dust $X$ Polais, in preparation

Fig.2. (a) Mean $\mathrm{SiO}_{2}$ (weight \%) of particles in the ash and dust layers of the Byrd core $( \pm 2 \bar{\sigma})$ vs depth (age). Time scale from Lorius and others (1984). Mean $\mathrm{SiO}_{2}$ of all particles in ash and dust bands is $60.9 \%$ and from Mount Takahe $61.2 \%$. (b) Mean $\mathrm{S} / \mathrm{Cl}$ ratio on particles from ash and dust layers.
Ice chemistry

In Figures 4(a), (b), and (c) the ice chemistry of three representative core sections with tephra (dust) layers (indicated by the arrows) is shown. Because of limitations in sample volume the profiles are not complete for all parameters. However, some general observations regarding the relationship between the concentration of ionic species in the ice to the presence of tephra layers can be made.

In general, conductivity and acidity of the ice are not well correlated with one another. However, the presence of dust seems to have affected the acidity and liquid conductivity of samples and has imposed an inverse relationship between them. Acidities typically range from -2 to $+2 \mu \mathrm{eq} \mathrm{r}^{-1}$ with peaks up to $6 \mu \mathrm{eq} \mathrm{r}^{-1}$ while conductivities are usually in the range -1 to $2 \mu \mathrm{S} \mathrm{cm}^{-1}$ with peaks up to $4 \mu \mathrm{S} \mathrm{cm} \mathrm{cm}^{-1}$. Although the neutralization of the acidity in these samples occurred in part during the analyses, a significant amount of neutralization probably also occurred in the atmosphere and in situ in the ice sheet.

Figure $4(a)$ is a representative section from about $1317 \mathrm{~m}$ depth in the core and shows that the samples in which tephra layers occur are alkaline and have relatively high conductivity although a general positive or negative correlation between the two parameters (acidity vs conductivity) does not exist. For example, a different pattern is shown in Figure 4(b), which shows a core section from about $1380 \mathrm{~m}$ depth where the tephra layers seem to be associated with ice having varying levels of acidity. Sporadic peaks in conductivity are not well correlated with the acidity peaks in this core interval. The difference in the ice chemistry of these two layers probably reflects variations in the amount of acids and tephra associated with the eruptions which produced them. Although the profiles are not complete, the evidence from these figures and the other ice-chemistry profiles, which will be discussed by Palais (in preparation), show that sulfate concentrations are only occasionally elevated in association with the tephra layers (compare sulfate profiles in Figures 4(a), (b), and (c)). Taken together with the low acidity of the ice, this evidence suggests that sulfur gases may have been only a

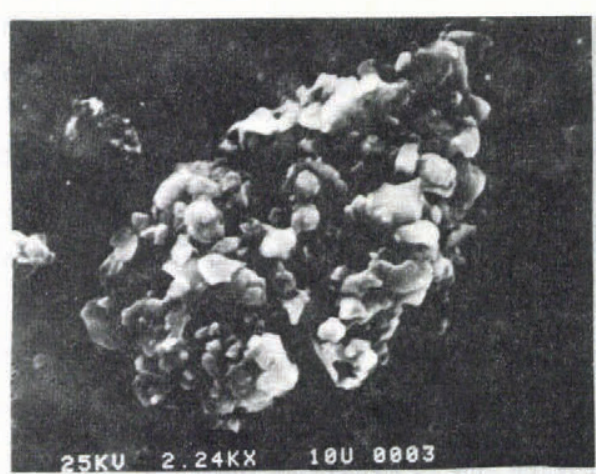

a

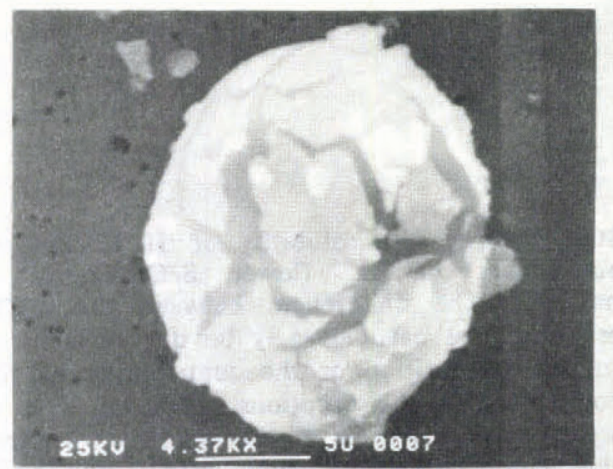

C

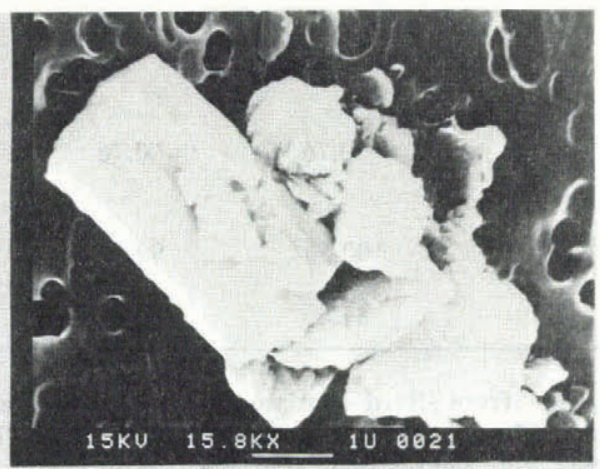

h

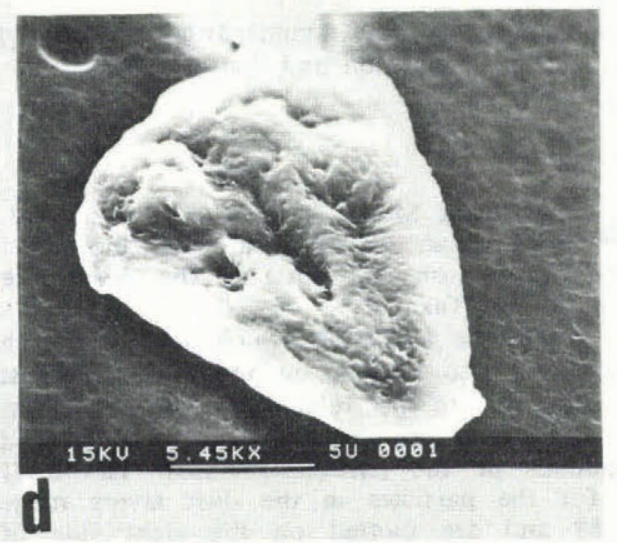

Fig. 3. SEM photographs of particles from the dust layers: (a) $1301 \mathrm{~m}$, aggregate of rounded vitric fragments, (b) $1317 \mathrm{~m}$, aggregate of crystal fragments, (c) $1301 \mathrm{~m}$, sphere with surface cracks and adhering particles, (d) $1347 \mathrm{~m}$, lithic fragment, surface alteration. 


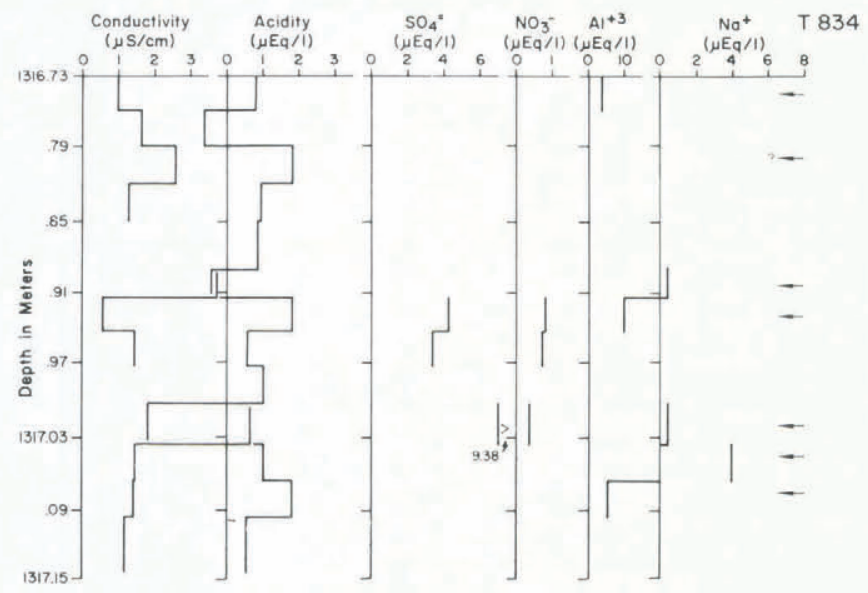

A

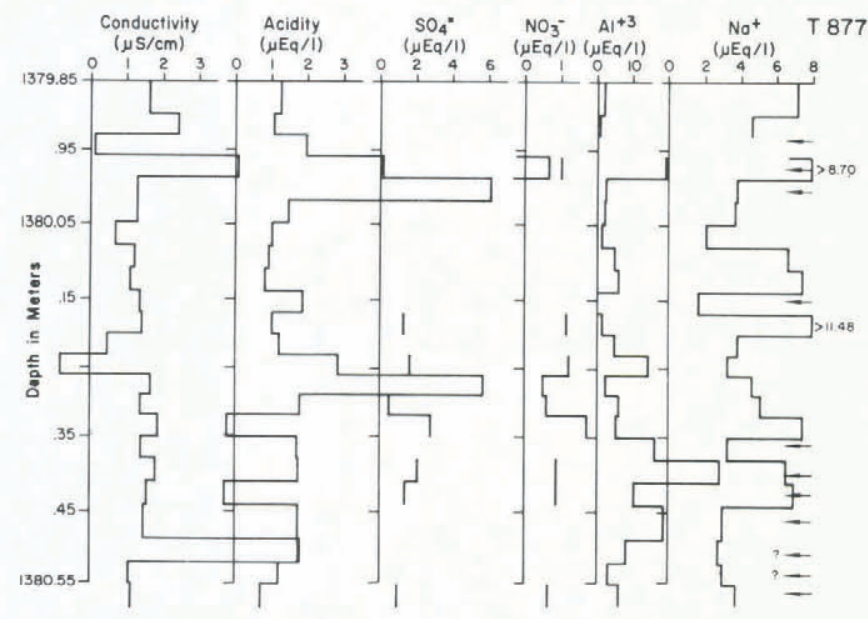

B

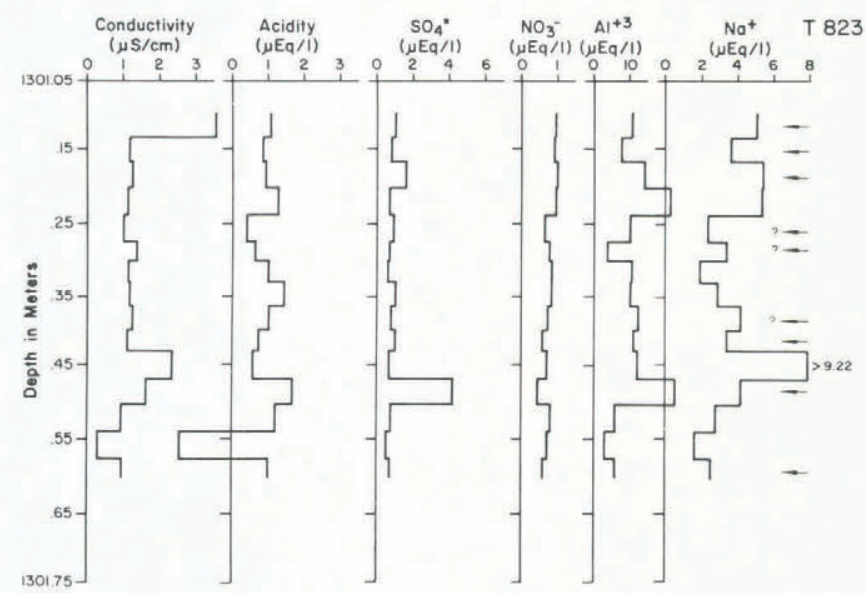

C

Fig.4. Ice-chemistry profiles from A) $1317 \mathrm{~m}$, B) $1380 \mathrm{~m}$, C) $1301 \mathrm{~m}$ in the Byrd core. The profiles include conductivity $\left(\mu \mathrm{S} \mathrm{cm}^{-1}\right)$, acidity, sulfate, nitrate, aluminum and sodium ( $\mu$ eq $\mathrm{1}^{-1}$ ). Arrows represent tephra layers.

minor product of the dust eruptions. Nitrate concentrations are unaffected by the presence of the tephra layers as shown in Figure 4(c) while Figures 4(b) and (c) demonstrate that the concentrations of aluminum and sodium are usually elevated in association with the tephra layers.

\section{CONCLUSION}

Evidence presented in this study suggests that the eruptions which produced the tephra layers in the Byrd core were from hydrovolcanic eruptions of Mount Takahe. This is based on detailed examinations of the particle morphology, composition and ice chemistry associated with tephra layers in the core. Melted glacier ice is the most likely source of the water for the hydrothermal system which may have existed at Mount Takahe.

Processes such as particle aggregation, rapid conversion of $\mathrm{SO}_{2}$ to $\mathrm{H}_{2} \mathrm{SO}_{4}$ and efficient scavenging of acid droplets by the abundant fine dust are characteristic of hydrovolcanic eruptions and are inferred to have taken place at Mount Takahe. Rapid aggregation and deposition of the fine acid-coated volcanic dust implies a short residence time for the tephra and gases and suggests that the eruptions had a minimal atmospheric-climatic impact.

\section{ACKNOWLEDGEMENTS}

Ice samples from the Byrd core were provided by the ice-core storage facility, State University of New York at Buffalo. Dr Tony Gow provided tephra samples from some of the ash layers and helpful information about the Byrd core. The SEM, EDAX and electron microprobe analyses were made at Los Alamos Scientific Laboratory in Los Alamos, New Mexico. Many thanks to Drs Grant Heiken and Ken Wohletz for the use of the facilities at Los Alamos and for helpful discussions concerning tephra. Ice-chemistry studies were made at the Laboratoire de Glaciologie in Grenoble, France. Discussions with Robert Delmas, Michel Legrand, Martine de Angelis, Jean-Robert Petit and Françoise Zanolini while the author was in Grenoble were extremely enlightening. Dr Gunter Faure made useful comments on the manuscript, and he, Dr Ellen Mosley-Thompson and $\mathrm{Dr}$ Philip Kyle provided important guidance in this work. Finally I would like to thank Dr Philip Kyle for allowing me to undertake this research which was funded by his grant DPP 8021402 from the National Science Foundation to the New Mexico Institute of Mining and Technology.

\section{REFERENCES}

Bence A E, Albee A L 1968 Empirical correction factors for the electron microanalysis of silicates and oxides. Journal of Geology 76: 382-403

Cragin J H, Herron M M, Langway C C Jr, Klouda G 1977 Interhemispheric comparison of changes in the composition of atmospheric precipitation during the Late Cenozoic era. In Dunbar $\mathrm{M} \mathrm{J}$ (ed) Polar oceans. Proceedings of the polar oceans conference.... Montreal....1974. Calgary, Arctic Institute of North America: 617-631

De Angelis $M$, Legrand $M$, Petit J-R, Barkov N I, Korotkevich Ye S, Kotlyakov V M 1984 Soluble impurities along the $950 \mathrm{~m}$ deep Vostok ice core (Antarctica) - climatic implications. Journal of Atmospheric Chemistry 1: 215-239

Gandrud B W, Lazrus A L 1981 Filter measurements of stratospheric sulfate and chloride in the eruption plume of Mount St. Helens. Science 211(4484): 826-827

Gow A J, Williamson T 1971 Volcanic ash in the Antarctic ice sheet and its possible climatic implications. Earth and Planetary Science Letters 13(1): 210-218

Gow A J, Ueda H T, Garfield D E 1968 Antarctic ice sheet: preliminary results of first core hole to bedrock. Science 161(3845): 1011-1013

Heiken G 1974 An atlas of volcanic ash. Smithsonian Contributions to the Earth Sciences 12

Kevex Corporation 1980 Quantex-ray instruction manual. Second edition. Foster City, CA, Kevex Corporation

Kyle P R, Jezek P A 1978 Composition of three tephra layers from the Byrd station ice core, Antarctica. Journal of Volcanology and Geothermal Research 4(3-4): 225-232

Kyle P R, Jezek P A, Mosley-Thompson E, Thompson L G 1981 Tephra layers in the Byrd station ice core and the Dome C ice core, Antarctica and their climatic importance. Journal of Volcanology and Geothermal Research 11(1): 29-39

Kyle P R, Palais J M, Delmas R 1982 The volcanic record of Antarctic ice cores: preliminary results and potential for future investigations. Annals of Glaciology 3: 172-177 
Langway C C Jr, Herron M M, Cragin J H 1974 Chemical profile of the Ross Ice Shelf at Little America V, Antarctica. Journal of Glaciology 13(69): 431-435

Legrand M 1980 Mesure de l'acidité et de la conductivité électrique des précipitations antarctiques. Centre National de la Recherche Scientifique. Laboratoire de Glaciologie et Géophysique de l'Environnement. Publication 316

Legrand M R, Aristarain A J, Delmas R J 1982 Acid titration of polar snow. Analytical Chemistry 54(8): 1336-1339

Legrand M, de Angelis M, Delmas R J 1984 Ion chromatographic determination of common ions at ultratrace levels in Antarctic snow and ice. Analytica Chimica Acta 156: 181-192

LeMasurier W E 1972 Volcanic record of Cenozoic glacial history of Marie Byrd Land. In Adie R J (ed) Antarctic geology and geophysics. Symposium...Oslo, 6-15 August 1970... Oslo, Universitetsforlaget: 251-259

Lorius C, Raynaud D, Petit J-R, Jouzel J, Merlivat L 1984 Late-glacial maximum-Holocene atmospheric and ice-thickness changes from Antarctic ice-core studies. Annals of Glaciology 5: 88-94

Palais J M, Legrand M 1985 Soluble impurities in the Byrd station ice core, Antarctica: their origin and sources. Journal of Geophysical Research 90(C1): 1143-1154

Ragone S E. Finelli R 1972 Use of atomic absorption spectroscopy in the determination of ug/liter concentrations of $\mathrm{Na}^{+}, \mathrm{K}^{+}, \mathrm{Ca}^{2+}$ and $\mathrm{Mg}^{2+}, C R R E L$ Special Report 174

Rose W I, Hoffman M F 1982 The May 18, 1980, eruption of Mount St. Helens: the nature of the eruption, with an atmospheric perspective. NASA Conference Publication 2240: $1-14$

Rose W I, Chuan R L, Woods D C 1982 Small particles in plumes of Mount St. Helens. Journal of Geophysical Research 87 (C7): 4956-4962

Rose W I, Wunderman R L, Hoffman M F, Gale L 1983 A volcanologist's review of atmospheric hazards of volcanic activity: Fuego and Mount St. Helens. Journal of Volcanology and Geothermal Research 17: 133-157

Sheridan M F, Wohletz K H 1983 Hydrovolcanism: basic considerations and review. Journal of Volcanology and Geothermal Research 17: 1-29

Sorem R K 1982 Volcanic ash clusters: tephra rafts and scavengers. Journal of Volcanology and Geothermal Research 13(1-2): 63-71

Stoiber R E, Williams S N, Malinconico L L 1980 Mount St. Helens, Washington, 1980 volcanic eruption: magmatic gas component during the first 16 days. Science 208(4449): 1258-1259

Stoiber R E, Williams S N, Malinconico L L, Johnston D A, Casadevall T J 1981 Mt. St. Helens: evidence of increased magmatic gas component. Journal of Volcanology and Geothermal Research 11: 203-212

Thompson L G, Hamilton W L, Bull C 1975 Climatological implications of microparticle concentrations in the ice core from "Byrd" Station, western Antarctica. Journal of Glaciology 14(72): 433-444

Thornton C P, Tuttle O F 1960 Chemistry of igneous rocks. 1. Differentiation index. American Journal of Science 258(9): 664-684

Walker G P L 1971 Grain size characteristics of pyroclastic deposits. Journal of Geology 79: 696-714

Wohletz K H 1983 Mechanisms of hydrovolcanic pyroclast formation: grain-size, scanning electron microscopy and experimental studies. Journal of Volcanology and Geothermal Research 17: 31-63 